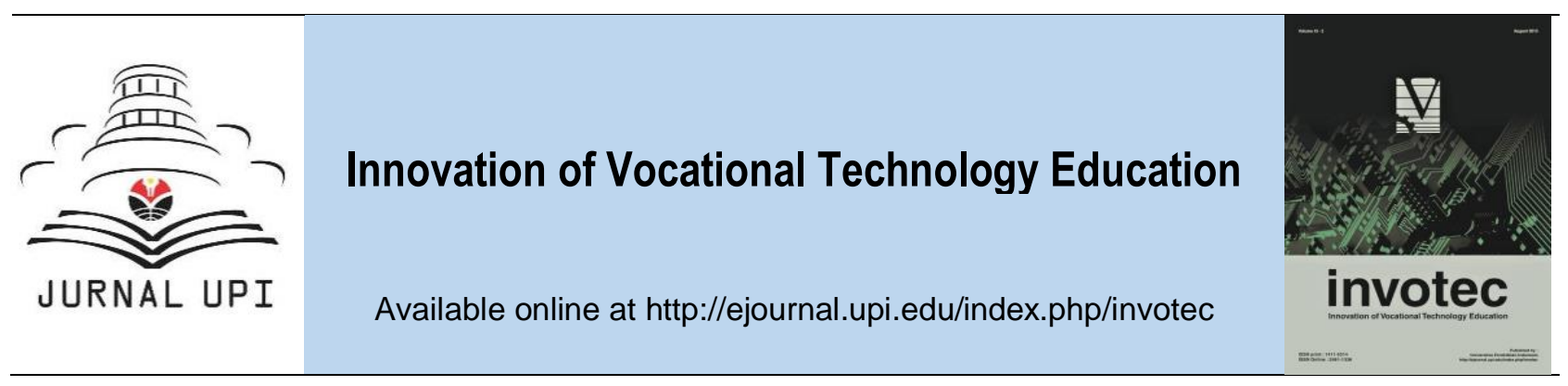

\title{
Argumentation and Reasoning Skills In Socioscientific Issues
}

\author{
A. L. Alindra \& A. Ana \\ Universitas Pendidikan Indonesia, Indonesia
}

\section{ARTICLE INFO}

Article history:

Received 20 June 2018

Received in revised form 22 July 2018

Accepted 20 August 2018

Available online 31 August 2018

Keywords:

Socioscientific Issue, Toulmin Argumentation

Pattern

Corresponding author: lailyalindra@gmail.com

\section{A B S T R A C T}

\begin{abstract}
Education is facing big challenges so that it can create qualify individuals in problem solving. Application of knowledge and or scientific concepts in the public is a realization of knowledge obtained by students at school. There are several ways to develop science education, one of which is through argumentation skill towards socioscientific issues. The socioscientific issue is scientific concept and problem-based issue, controversy, public discussion greatly influenced by sociopolitics. This writing by literature study method aims to explore on argumentation skill for students so that they can face any problem solving challenges in daily life by studying; application of argumentation skill for socio scientific issue in daily life, argumentation and reasoning as well as Toulmin Argumentation Patter as the pattern used in student argumentation skill access.
\end{abstract}

\section{Introduction}

Scientific education is one of the means to create qualify humans in terms of thinking and acting so that they are expected to have be able to serve a role as good community member. Through scientific education, students are expected to develop any necessary knowledge, thinking process and attitude in achieving national education objectives. Knowledge, thinking process and attitude owned by students are an accumulation of their educational experiences and process (Anderson, 2012).

There are several ways to develop science education, one of which is through argumentation skill towards socioscientific issues. The socioscientific issue is scientific concept and problem-based issue, controversy, public discussion greatly influenced by socio-politics (Sadler \& Zeidler, 2005). Argumentation skill is one of the determinants for student success in playing their role in the community since it relates to one's ability in the best decision making in facing problem solving (Erduran,, et. al., 2004).

Along with it, recently teachers are faced by limited time and many curriculum contents, so they lack to explore and develop student argumentation toward socioscientific issues. From results of review on case study conducted by the author on senior high school students' argumentation skill in Bandung city on socioscientific issue context, it is obtained that there is still low mean of students' argumentation skill, namely in level 1 and some in level2. This achievement shows that new students have argumentation skill as simple claim versus reclaim or claim versus claim (Erduran, Simon, and Osborne, 2004). This result describes low level of students' argumentation skill in reasoning so that they still deliver low argumentation in discussing socio scientific issues. Thus, it is necessary to develop the socioscientific issue and use it as meaningful learning experiences in scientific 
education. Many argumentations are used as an important component in relating scientific education and its material content understanding (Cetin, Dogan, \& Kutluca, 2014).

In its application in the world of education, the socio-scientific issue has become important in science education since it serves a central role in scientific literacy process (Venville \& Dawson, 2010). Science literacy requires ability to discuss, interpret relevant evidence, and draw conclusions related to the socio-scientific issues. As expressed by Driver, et. al. (2000), putting socio-scientific issues in the learning process is important in order to produce a responsible society which is able to apply scientific knowledge, and have thinking ability.

Sociocultural perspectives describe individual condition and how their behavior is influenced by special factors in surrounding socio-cultural environment. A personal development study is not only on the individual or on the environment aspect, but also on the social and cultural context (Hasnunidah \& Susilo, 2014). Vygotsky (1978) with his sociocultural theory stated that students acquire various knowledge and skills through interaction with their social environment. Thus, constructing knowledge is a social process involving communities in their environment. Rogof (1993) believes that argumentation activities are part of a social process to develop scientific discourse in learning Science.

It is necessary to pay attention to the development of argumentation activities in the Science learning environment, especially in facing current globalization era. According to Lemke (1990) it is necessary for students to be given opportunity to be actively involved in arguments in order to use scientific language or communicate scientifically. This is consistent with the UN consensus that science education in the $21^{\text {st }}$ century must be able to build knowledgeable communities through ICT and media literacy skills, critical thinking skills, problem solving skills, effective communication skills, and collaborative skills (Kusnandar, 2008). Argumentation is also an important tool for teaching critical thinking (Marttunen, 1994). Critical thinking skills are very essential in socializing today, especially in a sociocultural perspective.

\section{Methods}

The method used is the literature study method. The study of books, literature, and scientific articles is conducted to enrich the study of argumentation skills. Secondary data from various results of research or experiments is a type of data which is then synthesized to create a unity in providing information. This research method is divided into two main parts, namely the search and sorting phase and the data analysis stage. This research is limited to the topic of argumentation and reasoning. Then further review of this topic refers to empirical findings. The first step is to search and sort electronic databases using key words argumentation and reasoning skills. This electronic database is used as a reference for research obtained from Wiley, Proquest, ERIC and researchgates.

The next stage is the data analysis stage. Where the database has been collected and sorted and then analyzed according to the purpose of writing this literature review. Each article is read, analyzed and summarized by paraphrasing the research method, results and/or discussion according to the needs of writing this literature review study. This is done repeatedly for all databases that have been owned and according to the topic of this research topic.

\section{Result and Discussion}

Argument is an explanation on a solution related to claim substance, data, evidences and supports serving contribution in argument content, meanwhile argumentation relates to process to obtain and compile the components (Duschl \& Osborne, 2002). There are many experts define argumentation, among others are Stephen Toulmin, Edward S. Inch, and Watson. These three experts basically define argumentation as a discourse express by a person for the sake of ensuring and proving truth of the proposed discourse. Argumentation is a form of communication to externalize the reasoning through a series of scientific discourse as a very important process in the learning process (Hasnunidah \& Susilo, 2014).

Reasoning comes from the word reason, literally means as reason. Then, reasoning or to reason is to give or think reasons. Reasoning from theoretical aspect can be defined as a logical and systematic thinking process to create and evaluate a belief on a statement of assertion. The main function of reasoning is argumentative: Reasoning has evolved and persisted mainly because it 
makes human communication more effective and advantageous. As most evolutionary hypotheses, this claim runs the risk of being perceived as another "just so story." It is therefore crucial to show that it entails falsifiable predictions. If the main function of reasoning is indeed argumentative, then it should exhibit as signature effects strengths and weaknesses related to the relative importance of this function compared to other potential functions of reasoning (Mercier \& Sperber, 2011).

Judging from the theory definition, there are 3 components forming the reasoning, namely, assertions, beliefs, and arguments. Assertion is an affirmation of something or reality expressed in the form of sentences or expressions. This assertion must be quantified to limit universal / general assertions so that it can be specific and determine inclusion, exclusion, mutually-related relationships. Assertion is input from reasoning. Arguments are processes of reasoning, namely the process of interfering existing statements. Then, belief on valid conclusion statement is output of reasoning. Argument is a series of assertions along with inference or conclusion, as an important point in reasoning. This argument is a rational proof of a statement validity. Meaning, arguments function to maintain, form, or change beliefs.

Critical reasoning can be obtained and illustrated by drawing conclusions through skeptical intelligence by thinking, assumptions, and evidences obtained from the individual or from others. Learners can re-learn any arguments they make through their skepptic thinking so that they can improve their thinking about their arguments (Barnet \& Bedau, 2011).

Reasoning skill plays an important role in educational implications. Very high level of reasoning skills are needed not only in making decisions and solving problems. High scientific reasoning will influence on students' ability to solve problems. It is necessary for emphasis to train students' reasoning skills (Ding, 2014) and problem solving skills (PISA, 2013).

As a consequence of the decision-making process, arguments and arguments play an important role in informal reasoning (Means \& Voss, 1996) and argumentation is an external expression of informal reasoning (Sadler \& Zeidler, 2005). Kuhn (1991) defined arguments as a statement with justification, Means and Voss (1996) describe arguments as 'conclusions supported by at least one reason Means and Voss (1996) continue to claim that informal reasoning is a rather fuzzy construct, informal reasoning is a skill in giving arguments. Therefore, argumentation skills are used when scientific students share with others about their scientific knowledge in the form of dialogical discourse in decision making about sociosocial issues (Osborne, Erduran, \& Simon, 2004). Then, Sampson \& Clark (2008) distinguish arguments and argumentation by using the term of 'argument' to describe students' reasoning result products in making and justifying claims; and the term of 'argumentation' to describe complex processes.

Stephen Toulmin in 1985 provided a way to measure any patterns found in argumentation. The argumentation pattern was known as Toulmin's Argumentation Pattern (TAP). The argumentation criteria given by Toulmin show eight important benefits of using argumentation, namely, clarity about any issues to be raised, clarity of argument main objectives, relevant basis to claims, basis used to support claims, applied warranty for discussion, warranty based by strong advocates, claim strength created from arguments, possible rebuttal for better understanding. Toulmin's model applies not only to arguments, whose authors address verbalized reasoning to someone else, but also to solo verbal reasoning, in which reasoners draw conclusions for themselves from information at their disposal. I shall propose guidelines for such reasoning, from the perspective of someone about to engage in it rather than of someone critically evaluating it after the fact. Solo verbal reasoning as I understand it must have some verbal components (merely thought, spoken aloud, written, signed, etc.) but can have non-verbal (Hitchcock, 2005).

This Toulmin model is not only applicable for written arguments, but is also widely used for single verbal reasoning, where speakers make conclusions based on any obtained information. Toulmin defines the argumentation component as reasoning from the data to create claims by using warrant following the evidence, taking into account the support for warrant and proposing qualifications and objections to claims. These argument components were initially developed by Toulmin in the fields of rhetoric and communication, but in its development, it was used in broader fields such as science (Bulgren, Ellis, \& Marquis, 2014).

Toulmin (2003) said that an argument is obtained from a series of interrelated sentences and based on a statement that is believed for its truth, namely claim (C), with data (D) that has been tested, and related via warrant $(\mathrm{W})$ and reinforced with backings $(\mathrm{B})$. Arguments are challenged in rebuttals $(R)$, or counter-arguments that present contrary facts to data, warrant or backings, thus 
proving that the statement is true. Qualifiers $(Q)$ show conclusion strength and its application and validity. Visually, the Toulmin argument cycle steps can be seen in figure 1 below:

\section{Claim}

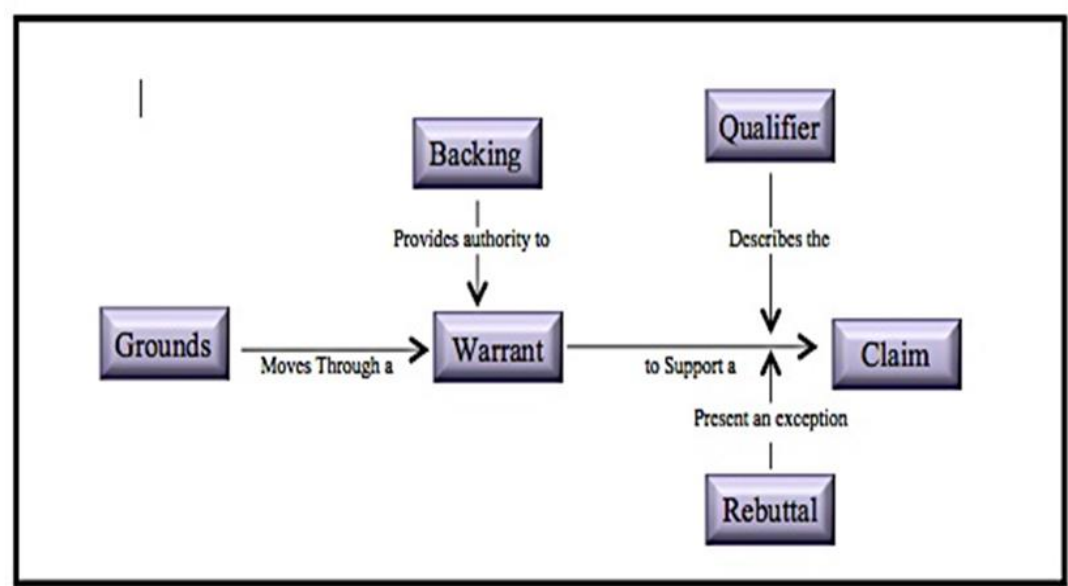

Figure 1. Toulmin Argument Pattern (TAP) (Toulmin, 1984)

Each argument has a purpose, namely to establish a claim (conclusion or thesis). A claim is a disputed/debatable statement - a rhetorical idea (namely a speaker or writer) asks other person to accept. Or it is also called as a debatable statement. Three types of persuasive claims: (1) the fact claim confirms that something is true or not true; (2) value claims confirm that something is good or bad, less or more desirable, and (3) policy claims confirm that one action is superior to another. Examples of claims can be seen as follows: 'I think we should have universal health care'. A claim expresses a specific position to a controversial and dubious problem, the claimant certainly wants the audience to accept the claim. When other parties or opponents reject the stated claims (especially complex claims), it is very useful to reject the claim by identifying created claims. A good claim debate is debatable claims so that there will be various supporting data and warrants.

\section{Ground/Data}

Arguments that have been disclosed or that have been thought will require evidence, reason, or referred to as ground (basis/data) as a basis for claims. The premises are the ground of the deductive argument, while the evidence is ground of the inductive argument. An example that can be taken is observation or an experiment that can make a possible or allowable claim.

Not every claim can be supported by various grounds, since not all grounds provide good support for every claim. The following are examples that can be given regarding ground (Barnet \& Bedau, 2011):

a. I can count all women and men. Let's just say the number is all 50 people. If the number of women is 25 people and the number of men is 25 , then I have been able to maintain the claim that I put forward.

b. I can count at least 10 students, 5 of whom are female students. Thus I have obtained ground from the claim.

c. I can show that students in a class at the university have the same number of men and women and claim that the class can represent an example for the entire university.

Based on the example above it can be seen that ground 1 is stronger than ground 2 , and ground 2 is stronger than ground 3.

\section{Warrant}

It is certainly necessary for a claim to offer evidence or reasons to support it, so the question will be "why do those reasons support this conclusion (claim)?". Warrants can help provide a basis for claim formation that connects ground / data and claims. Warrant is a general rule to identify relationship of a claim with data. Warrants can be implicit or explicit, but in any case, warrant is not the same as the presidential (rationale) in other words, warrants are rules for giving inference licenses. Toulmin stated that warrant consists of a range of specific texts that are directly related to 
created arguments. One important point made by Toulmin is that warrant is a type of inference (conclusion) rule and particularly, it is not a statement of fact.

\section{Backing}

Explaining backing or support or explanation in supporting warran so that it can explain on ground / data relationship to claims is indeed not easy. A distinctive feature of support is the word 'because' in an argument sentence. Support strengthens any given warran, Toulmin stated that difference between backing and data is that backing can be categorized as a statement in the form of fact, similar to data / ground, whereas warran is a generalization (Toulmin, 2003). Backing can also be used as required evidence in study collection.

\section{Qualifier}

The previous four patterns in argumentation can be categorized as follows: claim (maintainable conclusions), ground or data (explicitly visible reasons), warrant (principle that connects ground to claim), and backing (implicit assumptions). All such propositions have a qualifier modality to show the scope and character that is believed to be true. Are these claims, for example, believed to be necessary - or just might be necessary? Are these claims believed to be reasonable-or might they make sense? Out of both reasons for claiming, they may be good, but they may be better than others. Showing modalities with a proposed statement is very important for argument or rejection of any argument.

Empirical generalizations usually depend on a variety of factors, and it is important to show such contingencies to protect the public from real examples. So, consider this empirical generalization: qualifiers are also called affirmations or conditions, which have varying scope that are as important as other parts of Toulmin's argumentation pattern. Quantifiers can be represented by words: only, rarely, often, sometimes, perhaps, usually, more or less, regularly, sometimes.

\section{Rebuttal}

Rebuttal or also called as counterclaim also referred to as a rebuttal to a claim. This rebuttal is the opposite of the claim expressed by someone. Rebuttal can be stated by people who claim to be able to corroborate claims.

It is necessaty to pay attention to the development of argumentation activities in the Science learning environment, especially in facing current globalization era. According to Lemke (1990), it is necessary for students to be given opportunity to be actively involved in arguments in order to use scientific language or communicate scientifically. This is consistent with the UN consensus that science education in the 21 st century must be able to build knowledgeable communities through ICT and media literacy skills, critical thinking skills, problem solving skills, effective communication skills, and collaborative skills (Kusnandar, 2008). Argumentation is also an important tool for teaching critical thinking (Marttunen, 1994). Critical thinking skills are very essential in socializing today, especially in a sociocultural perspective

The argumentation skills in science learning, especially biology at schools can be related to biological concepts with controversial characteristics; this can lead to debate in the public domain and sometimes influence on public political and social conditions (Sadler \& Zeidler, 2005). Any problems involving social aspects and are related to the application of science principles and practices are called as socio-scientific issues (Sadler \& Fowler, 2006). Socio-scientific issues are seen as a good context to see quality of student argumentation skills because in the context of socioscientific issues, there are more than one scientific concept to explain the same phenomenon (Acar, et. al., 2010). socio-scientific issues are issues based on concepts or scientific problems, controversial in nature, a general conversation in society, and are often subject to political and social influences (Sadler \& Zeidler, 2005).

The reasoning mechanism can be measured by determining argumentation structure made by students based on data and knowledge about science material. Teachers often ignore this reasoning in measuring students' learning success. Educators rarely conduct studies using arguments in measuring material understanding, so there will be no critical thinking processes (Bathgate, et al., 2015). Therefore, building argumentation skills is in line with building students' reasoning.

Students in Indonesia have a high sensitivity and curiosity towards the sociological issues in Indonesia. This was said by a teacher in second grade of senior high school in Bogor Indonesia, "when SARS (Severe Acute Repiratory Syndrome) outbreak hit Indonesia, the students asked to be 
taught about this disease mechanism caused by a virus. But the student's request was neglected since the teacher had to obey applicable curriculum order at school. He could also only able to say, "In Class X (ten) you have learned it first. Please help yourself!" This experience may have been experienced by other teachers. Limitations of time and space are often the reason for teachers, even though in such information and communication technology era, as now, there should be no any these constraints (Herlanti, et. al., 2012).

The problem above is just a case example of science learning in the classroom. Furthermore, in Indonesia, there are a lot of social issues in Biology learning. Some of which are themes of environmental problems, genetics, biotechnology, engineering products, and so on. These issues can be presented in Biology learning to build students' argumentation skills. Therefore, it is necessary for a study of the social issues to be developed in learning science, especially Biology. The examples of instruments in measuring argumentation skills in scientific sausage issues can be seen as follows:

\section{Examples of Instrument in Measuring Argumentation Pattern in Socio-Scientific Issues}

The following is the example of instruments to measure argumentation skills (Table 1) and instrument of argumentation quality rubric (Table 2) using framework Toulmin's Argumentation Pattern (TAP).

Table 1. Examples of instrument to measure argumentation complexity

\begin{tabular}{|c|c|c|}
\hline No. question & Socio-scientific issues & Details of question items \\
\hline 1 & $\begin{array}{l}\text { Use of food preservatives } \\
\text { used by farmers in } \\
\text { vegetables and fruits that } \\
\text { will be exported }\end{array}$ & $\begin{array}{l}\text { a. What do you think about the use of preservatives } \\
\text { needed by farmers to export vegetables and fruit? } \\
\text { b. Give reasons in the form of evidences to support } \\
\text { your opinion regarding the use of preservatives } \\
\text { needed by farmers to export vegetables and fruits! } \\
\text { c. How do you convince others to agree with your } \\
\text { opinion? }\end{array}$ \\
\hline 2 & $\begin{array}{l}\text { Flavoring (MSG) content in } \\
\text { junk food is preferred by } \\
\text { children }\end{array}$ & $\begin{array}{l}\text { a. What do you think of mothers who give nuggets, } \\
\text { sausages, or fried chicken on the food menu so their } \\
\text { children want to eat? } \\
\text { b. Give reasons in the form of evidences to support } \\
\text { your opinion about mothers who provide nuggets, } \\
\text { sausages, or fried chicken on their children's food } \\
\text { menu so their children want to eat! } \\
\text { c. How do you convince others to agree with your } \\
\text { opinion? }\end{array}$ \\
\hline 3 & $\begin{array}{l}\text { Use of food coloring used } \\
\text { by cake sellers }\end{array}$ & $\begin{array}{l}\text { a. What do you think about addition of artificial coloring } \\
\text { used by cake seller so that the cake is sold? } \\
\text { b. Give a reason in the form of evidences to support } \\
\text { your opinion on addition of artificial coloring used by } \\
\text { cake sellers so that the cake is sold! } \\
\text { c. How do you convince others to agree with your } \\
\text { opinion? }\end{array}$ \\
\hline 4 & Smoking habits in elderly & $\begin{array}{l}\text { a. What do you think about habits of some parents } \\
\text { (more than } 30 \text { years old) who find it difficult to give } \\
\text { up smoking? } \\
\text { b. Give reasons in the form of evidences to support } \\
\text { your opinion! } \\
\text { c. How do you convince others to agree with your } \\
\text { opinion? }\end{array}$ \\
\hline
\end{tabular}


Table 2. Example of argumentation quality measurement rubric

\begin{tabular}{cll}
\hline Score & \multicolumn{1}{c}{ Reference } & \multicolumn{1}{c}{ Answer examples } \\
\hline 0 & No claim & I do not know / I do not have any idea about this issue \\
\hline 1 & $\begin{array}{l}\text { Claim without wrong scientific } \\
\text { justification }\end{array}$ & $\begin{array}{l}\text { Yes, it should be / not be conducted, it should not be } \\
\text { conducted since the gen will be mixed with soil }\end{array}$ \\
\hline 2 & Claim with simple justification & $\begin{array}{l}\text { Yes it should be conducted if it is beneficial since it will } \\
\text { be not fair. }\end{array}$ \\
\hline 3 & $\begin{array}{l}\text { Claim with one or more than } \\
\text { detailed justification or counter - } \\
\text { argument }\end{array}$ & $\begin{array}{l}\text { No, since it can change natural balance to one of the } \\
\text { gender in which this will cause to social divisions. } \\
\text { However, sex determination can be reserved in case of } \\
\text { a sexually transmitted disease so that inheritance in } \\
\text { the next generation can be prevented. }\end{array}$ \\
\hline
\end{tabular}

Example of Analysis Framework Used to Assess Argumentation Quality follows:

Erduran, Simon, and Osborne (2004) provide levels for argumentation quality assessment as

Level 1: consists of arguments which are simple claims versus re-claims or claims versus claims.

Level 2: arguments have arguments consisting of claims versus claims with data, warrant or backing but do not contain any objections.

Level 3: arguments have arguments with a series of claims or objections with data, warrant or supporters with occasional weak arguments.

Level 4: shows arguments with claims with clear disclaimers. Such an argument might have some claims and counter allegations too.

Level 5: arguments display extended arguments with more than one argument.

For example, in a study by Simon (2008) the use of the Toulmin Argument Pattern for evaluating arguments in science learning results is obtained the results in the form of example of leveling students' argumentation skills as shown in the following figure 2:

In this lesson the focus has been 'Evaluating argument'. I am looking at how argument can be assessed. I have chosen to focus on spoken argument during class discussions. The 'Level of argument' sheet was used to identify claim, data, warrants and rebuttals in pupils' conversations. What follows is an attempt to analyse particular parts of the lesson that I recorded in writing.

$\begin{array}{lll}\text { Level 1 } & \text { Fateha } & \text { I agree with it } \\ & \text { John } & \text { No it's bad } \\ & \text { Fahmida } & \text { Idon't know } \\ & \text { John } & \text { It's bad, I know }\end{array}$

This shows a claim from Fateha. John just disagrees - a counter claim. Fahmida doesn't help. John repeats what he had said before, but still doesn't explain why.

Level 2 Jake responded to Vincent

$\begin{array}{ll}\text { Jake } & \text { So this means it is bad for health because we } \\ & \text { are eating it } \\ \text { Vincent } & \text { Well, I haven't died } \\ \text { Jake } & \text { But you don't know if it's doing something } \\ & \text { inside. }\end{array}$

This conversation shows a claim by Jake followed by Vincent backing his claim with 'weak' data - 'Well, I haven't died'. 


$\begin{array}{ll}\text { Level } 3 \text { Fateha } & \text { We can have more food and people need it. } \\ \text { John } & \text { But it's bad because it's not natural } \\ \text { Fatena } & \text { What, plants or genes? } \\ \text { John } & \text { No changing it like that } \\ \text { Fatena } & \text { And it grows quicker } \\ \text { John } & \text { Because you can't change it back }\end{array}$

John has included a rebuttal - 'changing genes' is not 'natural' and implies danger when he adds the data 'because you can't change it back'. However, it doesn't carry much weight. John does not explain fully how his evidence related to his argument, so I assume it to be a Level 3 .

Level 4 Luke steps into the conversation between Fateha and John, in support of

John.

Luke Yeh, its like sometimes the changes can do a bad thing, like getting it to be bad for the soil, or it makes it dangerous and if that happens it spreads and you canit stop it.

Luke reiterates what John said but makes a stronger rebuttal this time.

$\begin{array}{ll}\text { Level } 5 \text { John } & \text { GM food is not good } \\ \text { Fateha } & \text { I don't think so } \\ \text { Fahmida } & \text { It affects wildlife like insects so it has to be bad } \\ & \text { because of the food chain, so it will have an } \\ \text { effect on the environment like more or less } & \text { animals. It depends. }\end{array}$

Fateha talks to Rima to get her on side -

Rima Look, it says that more people can eat because it grows better, I don't know, so then the land will be less damaged because you have to grow less. And this is done so it doesn't get diseases and that.

The discussion starts with a simple claim 'it's not good' versus counter claim by Fateha. Fahmida offers data - it affects the environment, and also a warrant - because it affects the food chain causing an imbalance. Rima supports Fateha with a rebuttal - it will affect the land less because you have to grow less and there is less chance of the plant being diseased.

The challenge presented in an argumentation lesson is to make an effective argumentwhere all its components are present. It is important for pupils to offer reasons - data - to support their claim and, if they do not agree with the counter claim they should be able to work through the otherís thinking to find out exactly why it is they don't agree with it.

Figure 2. Analysis of Alice (Teacher) on Student's Argumentation (Simon, 2008)

In this case Alice (the teacher) is able to consider the argumentation complexity using a system level, which is claimed to help her to improve students' argumentation skills in the future by communicating evaluation of the quality criteria for argumentation (Figure 2). Even by its limitations, this research tool is used to compare the quality of student discourse by teachers as a means to develop an understanding of the argumentation quality. This study implication is that the use of the Toulmin Pattern as a methodological framework for analyzing argumentation skills can influence the practice of classroom learning for professional development of teachers who use this methodology. 


\section{Conclusion}

Science education can be developed, one of which is by the ability to argue towards sociocultural issues. The socio-scientific issues are scientific concept and problems -based issues, controversies, and public discussions that are greatly influenced by social politics. Arguments are reasoning processes, namely interfering process with existing statements. Then, belief that the conclusion statement is valid can be seen as output from reasoning. To evaluate the argumentation skills in science learning, it is used the Toulmin Argumentation Pattern obtained by leveling students' argumentation skills.

\section{References}

Acar, O., Turkmen, L., \& Roychoudhury, A. (2010). Student difficulties in socio-scientific argumentation and decision-making research findings: Crossing the borders of two research lines. International Journal of Science Education. 32(9), 1191-1206.

Anderson, C. (2012). On the nature of thought processes and their relationship to the accumulation of knowledge: The process of making a diagnosis. Dermatology Practical and Conceptual, 2(4), 47-62.

Barnet, S., \& Bedau, H. (2011). Critical Thinking, Reading, and Writing-A Brief Guide to Argument. (K. S. Henry, Ed.) (7th ed.). Boston: One World.

Bathgate, M., Crowell, A., a, Schunn, C., Cannady, M., \& Dorph, R. (2015). The Learning Benefits of Being Willing and Able to Engage in Scientific Argumentation. International Journal of Science Education, 37(10), 1590-1612.

Bulgren, J. A., Ellis, J. D., \& Marquis, J. G. (2014). The Use and Effectiveness of an Argumentation and Evaluation Intervention in Science Classes. Journal of Science Education and Technology, 23(1), 82-97.

Cetin, P. S., Dogan, N., \& Kutluca, A. Y. (2014). The Quality of Pre-service Science Teachers' Argumentation: Influence of Content Knowledge. Journal of Science Teacher Education. $1-23$.

Dawson, V. \& Venville, G.J. (2009) High-school Students' Informal Reasoning and Argumentation about Biotechnology: An indicator of scientific literacy?. International Journal of Science Education, 31(11), 1421-1445.

Ding, L. (2014). Verification of Causal Influences of Reasoning Skill and Epistemology on Physics Conceptual Learning. Physical Review Special Topics-Physics Education Research, 10(2), 1-5. accessed 2 November 2018. The American Physical Society. Online: http://journals.aps.org/prstper/pdf/.

Driver, R., Newton, P., \& Osborne, J. (2000). Establishing the norms of socioscientific argumentation in classrooms. Science Education, 84(3), 287- 312.

Erduran, S., Simon, S., \& Osborne, J. (2004). Tapping into argumentation: Developments in the application of Toulmin's Argumentation Pattern for studying science discourse. Science Education, 88(6), 915-933.

Hasnunidah, N. \& Susilo, H. (2014). Profile of Sociocultural Perspective of Students in Arguing in Basic Biology Courses. Proceeding Biology Education Conference. XI National Seminar on Biology Education FKIP UNS. 
Herlanti, Y., N. Y. Rustaman, I. Rohman, A. Fitriani. (2012). Argumentation Quality in Discussion on Microbiological Socioscientific Issues through Weblogs. Indonesian Science Education Journal, 1(2), 168-177.

Hitchcock, D. (2005). Good Reasoning on the Toulmin Model, Argumentation, 2005 (19) 373391. http://doi.org/10.1007/s10503-005-4422-y.

Kuhn, D. (1991). “The skills of argument”. Cambridge, England: Cambridge University Press.

Kusnandar, A. (2008). ICT for Learning. Module. Jakarta: Pustekom Depdiknas.

Lemke, J. (1990). Talking Science, Language, Learning and Values. New York: Ablex.

Marttunen, M. (1994). Assessing Argumentation Skills among Finnish University Students. Learning and Instruction, 4(94): 175-191.

Means, M. L., \& Voss, J. F. (1996). Who reasons well? Two studies of informed reasoning among children of different grade, ability, and knowledge levels. Cognition and Instruction, 14(2), 139-178.

Mercier, H., \& Sperber, D. (2011). Why do humans reason? arguments for an argumentative theory. Behavioral and Brain Sciences, 34(2), 57-74. doi:http://dx.doi.org/10.1017/S0140525X10000968

Nurhayati, N. L., Yuliati, N., Mufti. (2016) Scientific Reasoning Pattern and Physical Synthetic Problem Solving Ability. Jurnal Pendidikan: Teori, Penelitian, dan Pengembangan, 1(8):1594-1597.

Osborne, J., Erduran, S., \& Simon, S. (2004). Enhancing the quality of argumentation in school science. Journal of Research in Science Teaching, 41(10), 994-1020.

PISA. (2013). PISA 2012 Result: Creative Problem Solving Students Skills in Tackling Real-Life Problems (5). OECD.

Rogoff, B. (1993). Observing Sociocultural Activity on Three Planes. In Wertsch, J. V., del Río, P., and Alvarez, A. (Eds), In Sociocultural Studies of Mind (pp 139-163). New York: Cambridge University Press.

Sadler, T. D., \& Zeidler, D. L. (2005). Patterns of informal reasoning in the context of socioscientific decision making. International Journal of Science Education, 28(12), 1463-1488.

Sadler, T. D., \& Donelly, L. A. (2006). Socioscientific argumentation: The effect of content knowledge and morality. Journal of Research in Science Teaching, 42(1), 112-138.

Sadler, T. D., \& Fowler, S. R. (2006). A threshold model of content knowledge transfer for socioscientific argumentation. Science Education, 90(1), 986-1004.

Sampson, V., \& Clark, D.B., (2008). Assesment of the ways studentd generate arguments in science education: Current perspectives and recommendations for future directions. Science Education, 92(3), 447-472. doi: https://doi.org/10.1002/sce.20276

Toulmin, S. E. (1984). An Introduction to Reasoning, $2^{\text {nd }}$ edition, Macmillan, New York.

Toulmin, S. E. (2003). The Uses of Argument (Updated edition 2003). Cambridge: Cambridge University Press. 
Venville, G.J \& Dawson, V.M. (2010). The Impact of classroom intervention on grade 1 students' argumentation skills, informal reasoning, and conceptual understanding of science. Journal of Research in Science Teaching, 47 (8), 952-977.

Vygotsky, L. (1978). Mind in Society, The Developmental of Higher Psychological Process. Cambridge: Harvard University Press. 